\title{
Location Technique for Multiple Partial Discharge Sources using Independent Component Analysis and Direction of Arrival Method of Electromagnetic Waves based on Bayesian Network
}

\author{
Hirokazu Ishimaru Member (Nagoya Institute of Technology, ishimaru@nitech.ac.jp) \\ Masatake Kawada Member (The University of Tokushima, kawada@ee.tokushima-u.ac.jp)
}

Keywords: independent component analysis, bayesian network, partial discharge, radio sensing, electric power apparatus and facilities

\section{Introduction}

The purpose of this paper is to present a new method designed for locating multiple partial discharge (PD) sources using Indipendent Component Analysis (ICA) and direction of arrival method of electromagnetic (EM) waves based on Bayesian Network. The proposed method consists of the following steps. First, the observed signals are converted from the time domain to the frequency domain through the short time Fourier transform (STFT). As the result of this process, ICA for convolved mixture turns into ICA for instantaneous mixture. In order to separate mixed signals, we use the fast ICA algorithm that is based on negentropy as a measure of nongaussianity. Next, we apply the direction of arrival method using Bayesian Network to the separated source signals by ICA. Signal sources are estimated by calculating intersection point from the arrival angle. Simulation results showed that our method located multiple signal sources when multiple source signals were simulaneously generated.

\section{ICA}

Assume that $\mathrm{n}$ source signals are observed by $\mathrm{m}$ sensors. The estimated source signals $\mathbf{y}(\mathrm{t})=\left[\mathrm{y}_{1}(\mathrm{t}), \ldots, \mathrm{y}_{\mathrm{n}}(\mathrm{t})\right]^{\mathrm{H}}$ are expressed as:

$$
\mathbf{y}(t)=\mathbf{W}^{H} \mathbf{x}(t)
$$

where $\mathbf{W}=\left[\mathbf{w}_{1}, \ldots, \mathbf{w}_{\mathrm{m}}\right]$ is the unmixing matrix, $\mathbf{W}^{\mathrm{H}}$ stands for the Hermitian of $\mathbf{W}, \mathbf{x}(\mathrm{t})=\left[\mathrm{x}_{1}(\mathrm{t}), \ldots, \mathrm{x}_{\mathrm{m}}(\mathrm{t})\right]^{\mathrm{H}}$ is the observed signals. The fixed-point algorithm for one unit is

$$
\begin{aligned}
& \mathbf{w}_{k} \leftarrow E\left[\mathbf{x}\left(\mathbf{w}_{k}^{H} \mathbf{x}\right)^{*} \mathrm{~g}\left(\left|\mathbf{w}_{k}^{H} \mathbf{x}\right|^{2}\right)\right] \\
& -E\left[\mathrm{~g}\left(\left|\mathbf{w}_{k}^{H} \mathbf{x}\right|^{2}\right)+\left|\mathbf{w}_{k}^{H} \mathbf{x}\right|^{2} \mathrm{~g}^{\prime}\left(\left|\mathbf{w}_{k}^{H} \mathbf{x}\right|^{2}\right)\right] \mathbf{w}_{k} \\
& \mathbf{w}_{k} \leftarrow \frac{\mathbf{w}_{k}}{\left\|\mathbf{w}_{k}\right\|}
\end{aligned}
$$

where $\mathbf{a}^{*}$ designates the complex conjugate of $\mathbf{a}$ and $\mathrm{g}(\mathrm{b})=1$ / $(0.1+b)$.

\section{Simulation}

We conducted a numerical simulation for locating multiple PD sources. Four source signals and four antennas (two 2-tuples) were set in the observable area. Any two sources were simulaneously generated. Convolutively mixed signals were received by two antenna pairs. The received signals were digitized at a sampling rate of $2.5 \mathrm{GHz}$ using a digital oscilloscope.

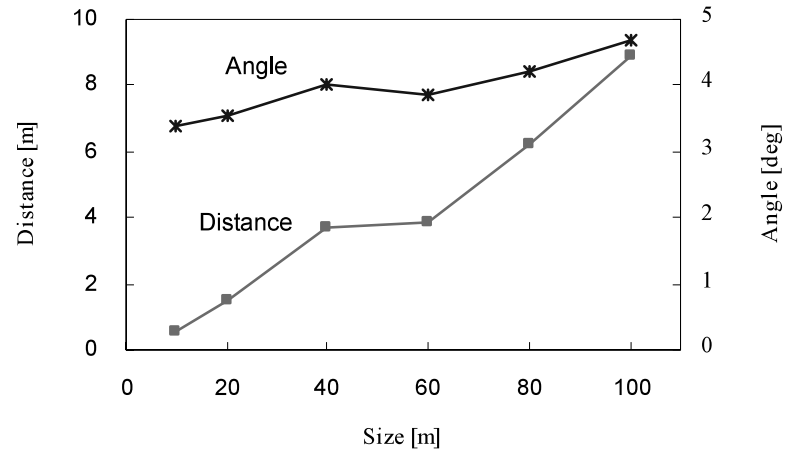

Fig. 1. Averaged estimation error

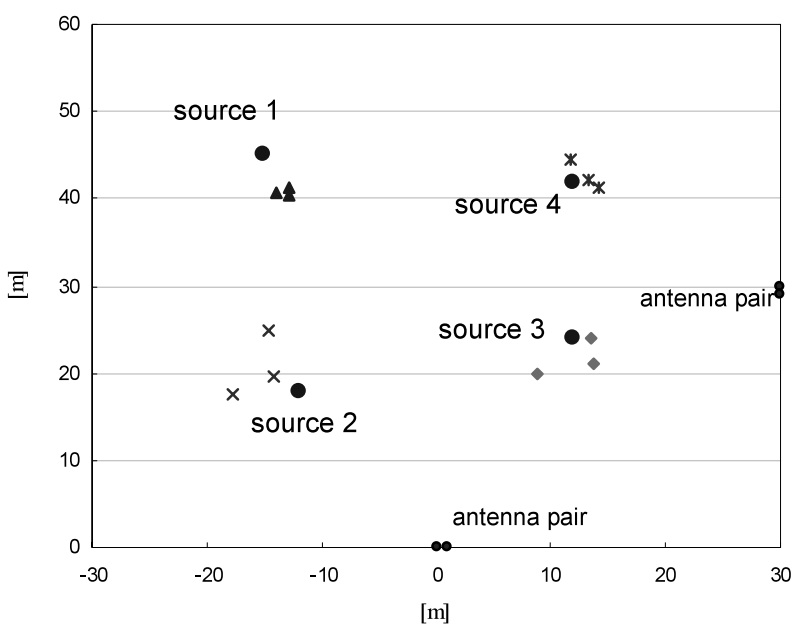

Fig. 2. Estimation result

The estimation error of distance and angle are shown as in Fig. 1. Average error was $0.59 \mathrm{~m}$ (distance) and $3.38 \mathrm{deg}$ (angle) in the observable area size $10 \mathrm{~m} * 10 \mathrm{~m}$. Average error increased proportional to observable area size. The location results of area size $60 \mathrm{~m} * 60 \mathrm{~m}$ are shown as in Fig. 2. Figure 2. shows the estimation error is less than $10 \mathrm{~m}$. As the results of the simulation, the proposed method is available to locate multiple PD sources. 


\title{
独立成分分析とベイジアンネットを適用した電磁波到来角推定法 による複数部分放電源の位置標定
}

\author{
正 員 石丸 宏一*,** 正員川田 昌武**
}

\author{
Location Technique for Multiple Partial Discharge Sources using Independent Component \\ Analysis and Direction of Arrival Method of Electromagnetic Waves based on \\ Bayesian Network
}

Hirokazu Ishimaru*,**, Member, Masatake Kawada**, Member

\begin{abstract}
We propose the new locating method for multiple partial discharge sources using independent component analysis (ICA) and direction of arrival method of electromagnetic (EM) waves based on Bayesian Network. The proposed method consists of the following steps. First, the observed signals are converted from the time domain to the frequency domain through the short time Fourier transform (STFT). As the result of this process, ICA for convolved mixture turns into ICA for instantaneous mixture. In order to separate mixed signals, we use the fast ICA algorithm (FastICA) that is based on negentropy as a measure of nongaussianity. Next, we apply the direction of arrival method of EM waves using Bayesian Network to the separated source signals by ICA. Signal sources are estimated by calculating intersection point from the arrival angle. Simulation results showed that our method located multiple signal sources when the observed signals were the convolved mixture of original sources.
\end{abstract}

キーワード：独立成分分析, ベイジアンネット，部分放電，電磁波センシング，電力機器・設備

Keywords: independent component analysis, bayesian network, partial discharge, radio sensing, electric power apparatus and facilities

\section{1. はじめに}

電力機器・設備の絶縁材料劣化に伴って生じる部分放電 (PD : Partial Discharge）の早期検出，位置標定技術の開発 は, 電力を安定供給する上で重要となっている。PD は広 帯域電磁波を放射することから，電磁波センシング技術に よる電力機器・設備の絶縁診断技術の開発が国内外機関に おいて進められている(1) (11)。

電力系統は各種機器・設備から構成されており, 電磁波 センシング技術を導入する上で，複数箇所から PD がほぼ 同時に発生する可能性や, 機器, 設備による電磁波の反射 に伴うマルチパスの影響を考慮する必要がある。

そこで, 本論文では独立成分分析 (ICA:Independent Component Analysis) ${ }^{(12)(13)}$ とベイジアンネットによる電磁波到

\footnotetext{
* 名古屋工業大学

于 466-8555 名古屋市昭和区御器所町

Nagoya Institute of Technology

Gokisocho, Showa-ku, Nagoya 466-8555

** 徳島大学大学院

干 770-8506 德島市南常三島町 2-1

The University of Tokushima

2-1, Minami-Johsanjima, Tokushima 770-8506
}

来角推定法 ${ }^{(1)}$ を用いた複数 PD 源の位置標定法を提案し, 数值シミュレーションにより, 本提案手法の有効性を示す。 なお, 数值シミュレーションでは, PD 源からの直接波がア ンテナで観測可能な環境を想定した。

\section{2. 独立成分分析による受信電磁波信号分離}

〈2・1〉 定 式 化 複数箇所で発生した PD 源からの 放射電磁波を受信する場合, 観測信号は各 PD から各アン テナへの到達時刻が異なることや, 反射によるマルチパス の影響から畳み込み混合となる。

$n$ 個の PD 源の原信号（放射電磁波）を

$$
\mathbf{s}(t)=\left[s_{1}(t), s_{2}(t), \ldots, s_{n}(t)\right]^{T} .
$$

とし, 放射電磁波の伝達時間ごとの減衰係数を $a_{i j}$ （イン パルス応答）とすると, 各アンテナにより受信した観測信 号は,

$$
\begin{aligned}
x_{i}(t) & =\sum_{j=1}^{n} \sum_{\tau=0}^{\infty} a_{i j}(\tau) s_{j}(t-\tau) \\
& =\sum_{j=1}^{n} a_{i j} * s_{j}(t) \\
\mathbf{x}(t) & =\mathbf{A}(t) * \mathbf{s}(t) \ldots \ldots \ldots \ldots
\end{aligned}
$$


で定義される。ここで， $m$ は観測信号数 (アンテナ数), $\mathbf{x}(t)=\left[x_{1}(t), \ldots, x_{m}(t)\right]^{T}$ であり,$n \leqq m$ である。 $\mathbf{A}$ は $a_{i j}$ を 要素とする混合行列である。実際の観測では, この混合行 列 $\mathbf{A}$ は，電磁波伝搬空間の特性，PD とアンテナ間の距離 による減衰，アンテナ特性，アンテナ間の相互結合等の要 素が含まれている。

なお, $n>m$ の場合は, 混合が非可逆となるため, 混合 行列 $\mathbf{A}$ の逆行列を計算することによって独立成分を求める ことはできない ${ }^{(12)}$ 。このような状況では過完備基底の ICA となるが，最尤推定を用いることで独立成分を推定するこ とができる ${ }^{(14)}$ 。ただし，計算量は FastICA と比べて膨大と なる。そこで, 本論文では $n \leqq m$ の場合についてのみ取り 扱った。

本論文では，観測信号に (4) 式の短時間フーリエ変換 （STFT：Short-Time Fourier Transform）を適用して，時間 周波数領域で表現する。

$$
X\left(f, t_{s}\right)=\sum_{t} e^{-j 2 \pi f t} x(t) \operatorname{win}\left(t-t_{s}\right)
$$

ここで, $f$ は周波数， $t_{s}$ は空関数の時間位置， $\operatorname{win}(t)$ は空関 数である。STFTにより，(3) 式は，

$$
\mathbf{X}\left(f, t_{s}\right)=\mathbf{A}^{\prime}(f) \mathbf{S}\left(f, t_{s}\right)
$$

$\mathbf{X}: \mathbf{x}$ の短時間フーリエ変換

$\mathbf{A}^{\prime}: \mathbf{A}$ の短時間フーリエ変換

$\mathrm{S}: \mathrm{s}$ の短時間フーリ工変換

に変換され，各周波数において瞬時混合の問題と見なすこ とができる。このように，STFTを適用することで畳み込 み混合を瞬時混合の問題に単純化して周波数ごとに ICA を 行う。

提案法では，混合行列 $\mathbf{A}$ は不明であると仮定しているが， 実際には，過去の診断結果から混合行列 $\mathbf{A}$ に関する事前知 識が利用できる場合も考えられる。過去の観測事例から， PD 放射電磁波の信号伝搬に関する事前知識が得られる場 合は，混合行列 $\mathbf{A}$ の各要素を確率分布として扱い，これら のベイズ事前分布を用いることで ICA 推定に事前知識を取 り入れ，効率的に推定を行うことができる ${ }^{(15)}$ 。

$\langle\mathbf{2} \cdot \mathbf{2}\rangle$ 白 色 化 ICA の前処理として観測信号の白 色化を行う。白色化により，次節で求める分離行列の推定 を直交行列に限定することになり，復元信号を互いに無相 関化することができる。ICAの前処理は，はじめに観測信 号の標本平均 $E[\mathbf{X}]$ を用いて, 観測信号 $\mathbf{X}$ を

$$
\mathbf{X} \leftarrow \mathbf{X}-E[\mathbf{X}]
$$

により，平均 0 に中心化する。次に，白色化行列

$$
\mathbf{V}=\mathbf{E D}^{-1 / 2} \mathbf{E}^{H}
$$

を用いて白色化を行う。 $\mathbf{E}$ は $\mathbf{X}$ の共分散行列 $E\left[\mathbf{X} \mathbf{X}^{\mathrm{H}}\right]$ の 固有ベクトルからなる直交行列である。 $\mathbf{D}$ は $\mathbf{E}$ の固有值か らなる対角行列であり, $\mathbf{D}=\operatorname{diag}\left(\mathrm{d}_{1}, \mathrm{~d}_{2}, \ldots, \mathrm{d}_{m}\right)$ で表され
る。また，H は共役複素転置を表す。白色化により，観測 信号 X は

$$
\mathbf{z}=\mathbf{V X}
$$

に線形変換される。

〈2・3〉 FastICA 本論文では ICA の計算上の効率的 手法である FastICA を用いており，以下にそのアルゴリズ ムを説明する。ICAでは分離行列 $\mathbf{W} に よ り ，$ 変換された 信号

$$
\mathbf{y}=\mathbf{W z}
$$

の各成分が独立となるような $\mathbf{W}$ を求める。本論文では, ICA の推定において独立性の基準に非ガウス性の最大化を 用いる。また，非ガウス性の定量的な尺度となるコントラ スト関数に

$$
J(\mathbf{w})=E\left[G\left(\left|\mathbf{w}^{H} \mathbf{z}\right|^{2}\right)\right]
$$

を使用する ${ }^{(12)(16)}$ 。ここで, $\mathrm{G}$ は滑らかな偶関数で, $\mathbf{w}$ は $m$ 次元複素ベクトルであり, $E\left[\left|\mathbf{w}^{\mathrm{H}} \mathbf{z}\right|^{2}\right]=1$ である。コントラ スト関数による推定值が外れ值に対して頑健（Robust）と なるためには，G が緩やかな増加関数であれば良いことか ら，本論文では $\mathrm{G}$ および，その導関数 $\mathrm{g}$ を，

$$
\begin{aligned}
& \mathrm{G}(\mathrm{y})=\log (0.1+\mathrm{y}) \\
& \mathrm{g}(\mathrm{y})=1.0 /(0.1+\mathrm{y})
\end{aligned}
$$

とする。

1 つの独立成分を推定するベクトルを $\mathbf{w}_{k}$ とすると，分離 行列 $\mathbf{W}=\left(\mathbf{w}_{1}, \ldots, \mathbf{w}_{n}\right)^{\mathrm{H}}$ を推定する FastICA のアルゴリズ ムは下記の通りである(12)(16)。

[Step 1］ ICA の前処理として，観測信号を平均 0 に中 心化した後，白色化する。

[Step 2] 推定する独立成分の数を $n$ とし, $k=1$ とおく。

[Step 3] ノルム 1 のベクトル $\mathbf{w}_{k}$ をランダムに設定する。

[Step 4] 次式で $\mathbf{w}_{k}$ を更新する。ただし，*は複素共役 である。

$$
\begin{aligned}
\mathbf{w}_{k} \leftarrow & E\left[\mathbf{z}\left(\mathbf{w}_{k}^{H} \mathbf{z}\right)^{*} \mathrm{~g}\left(\left|\mathbf{w}_{k}^{H} \mathbf{z}\right|^{2}\right)\right] \\
& -E\left[\mathrm{~g}\left(\left|\mathbf{w}_{k}^{H} \mathbf{z}\right|^{2}\right)+\left|\mathbf{w}_{k}^{H} \mathbf{z}\right|^{2} \mathrm{~g}^{\prime}\left(\left|\mathbf{w}_{k}^{H} \mathbf{z}\right|^{2}\right)\right] \mathbf{w}_{k}
\end{aligned}
$$

[Step 5] 次式で $\mathbf{w}_{k}$ の直交化を行う。

$$
\mathbf{w}_{k} \leftarrow \mathbf{w}_{k}-\sum_{j=1}^{k-1}\left(\mathbf{w}_{k}^{H} \mathbf{w}_{j}\right) \mathbf{w}_{j} .
$$

[Step 6] 次式で $\mathbf{w}_{k}$ の正規化を行う。

$$
\mathbf{w}_{k} \leftarrow \frac{\mathbf{w}_{k}}{\left\|\mathbf{w}_{k}\right\|} \text {. }
$$

[Step 7] $\mathbf{w}_{k}$ が収束していなければ，Step 4 に戻る。

[Step 8] $k=n$ ならば終了。それ以外は, $k=k+1$ と し, Step 3 に戻る。 
〈2・4〉 ICA の任意性 ICA では原信号 $\mathbf{s}$ および混合 行列 $\mathbf{A}$ に関する事前知識を利用せずに分離を行う。そのた め, 独立性を基準に分離された信号は，原信号の振幅值と 符号，順序を推定できないという任意性が残る。ここで順 序とは，分離後の信号 $\mathbf{y}$ の行成分の並び順を示し，対応す る独立成分 (原信号) が ICA を行う度に異なることを意味 する。本論文では，時間周波数領域において ICAにより分 離した信号を，独立成分ごとに周波数統合し，個々の信号 を復元する。なお，各周波数成分における信号の振幅值と 符号を観測時の出力值に復元し， $\mathbf{y}$ に示される独立成分の 順序を揃える必要があることから，分離行列の逆行列を利 用することで信号観測時の振幅值，符号を復元する。(8), (9) 式より,

$$
\mathbf{y}=\mathbf{W V X}
$$

となり, 両辺の左から分離行列の逆行列, 白色化行列の逆 行列を順に掛け，左辺と右辺を入れ替えると，

$$
\begin{aligned}
\mathbf{X} & =\mathbf{V}^{-1} \mathbf{W}^{-1} \mathbf{y} \\
& =\mathbf{V}^{-1} \mathbf{W}^{-1}\left(\begin{array}{c}
y_{1} \\
\vdots \\
0 \\
\vdots \\
0
\end{array}\right)+\cdots+\mathbf{V}^{-1} \mathbf{W}^{-1}\left(\begin{array}{c}
0 \\
\vdots \\
y_{i} \\
\vdots \\
0
\end{array}\right)+\cdots+\mathbf{V}^{-1} \mathbf{W}^{-1}\left(\begin{array}{c}
0 \\
\vdots \\
0 \\
\vdots \\
y_{n}
\end{array}\right) \\
& =\left(\begin{array}{c}
q_{1}^{1} \\
\vdots \\
q_{j}^{1} \\
\vdots \\
q_{m}^{1}
\end{array}\right)+\cdots+\left(\begin{array}{c}
q_{1}^{i} \\
\vdots \\
q_{j}^{i} \\
\vdots \\
q_{m}^{i}
\end{array}\right)+\cdots+\left(\begin{array}{c}
q_{1}^{n} \\
\vdots \\
q_{j}^{n} \\
\vdots \\
q_{m}^{n}
\end{array}\right) \ldots \ldots \ldots \ldots(17)
\end{aligned}
$$

と変形できる。但し, $\mathbf{V}^{-1} \mathbf{W}^{-1}\left[0, \ldots, y_{i}, \ldots, 0\right]^{\mathrm{H}}=\left[q_{1}^{i}, \ldots\right.$, $\left.q_{m}^{i}\right]^{\mathrm{H}}$ である。この変形により, 右辺 $i$ 番目の項 $\left(q^{i}\right)$ は $i$ 番 目の独立成分の観測信号を表し, 各項の $j$ 行目の成分 $\left(q_{j}\right)$ は $j$ 番目の観測地点（アンテナ）での值を表す。このよう に $\mathbf{y}$ を分解することで，独立成分ごとに各アンテナでの観 測信号を復元することができる。

次に, 順序の任意性を取り除くため, エンベロープ (Envelope）を利用して各周波数成分における独立成分の順序を並 べ替える ${ }^{(13)(17)}$ 。ここで, (17) 式の右辺 $i$ 番目の項 $\mathbf{z}\left(f, t_{s} ; i\right)$ を

$$
\begin{aligned}
\mathbf{z}\left(f, t_{s} ; i\right) & =\mathbf{V}^{-1} \mathbf{W}^{-1}\left(\begin{array}{c}
0 \\
\vdots \\
y_{i} \\
\vdots \\
0
\end{array}\right) \\
& =\left(\begin{array}{c}
q_{1}^{i} \\
\vdots \\
q_{m}^{i}
\end{array}\right) \ldots \ldots \ldots \ldots \ldots \ldots \ldots \ldots
\end{aligned}
$$

とおき，エンベロープを推定するためのオペレータ $\varepsilon$ を

$$
\varepsilon \mathbf{z}\left(f, t_{s} ; i\right)=\frac{1}{2 M+1} \sum_{\tau=t_{s}-M}^{t_{s}+M} \sum_{j=1}^{m}\left|\mathbf{z}_{j}(f, \tau ; i)\right| \cdots \cdots
$$

と定義する。ただし， $M$ は適当な正の定数, $\mathbf{z}_{j}\left(f, t_{s} ; i\right)$ は $\mathbf{z}\left(f, t_{s} ; i\right)$ の第 $j$ 成分とする。本論文では, $M$ の值を決定す るため, 予め模擬波形（5 章で用いる (25), (26) 式。なお, 信号源の配置は 5 章のシミュレーションと異なる複数の配 置とした。）による信号分離のシミュレーションを行った。 このシミュレーションでは, ICAにより分離した信号と原 信号の平均二乗誤差が最小となる $M$ の值を求めた。これに より，M=5とした。

エンベロープの相関によって独立成分の類似性を測るこ とで, 各周波数において同じ原信号と推定される独立成分 の組合せを求める。以下に，並べ替えの手順を示す ${ }^{(13)(17) 。 ~}$

[Step 1] 独立成分のエンベロープの相関が小さい順に周 波数を並べ替える。エンベロープの相関は次式で定義する。

$$
\begin{aligned}
& \operatorname{sim}(f)=\sum_{i \neq j} \frac{\varepsilon \mathbf{Z}(f ; i) \cdot \varepsilon \mathbf{Z}(f ; j)}{\|\varepsilon \mathbf{z}(f ; i)\| \cdot\|\varepsilon \mathbf{Z}(f ; j)\|} \\
& \operatorname{sim}\left(f_{1}\right) \leq \operatorname{sim}\left(f_{2}\right) \leq \cdots \leq \operatorname{sim}\left(f_{N}\right) .
\end{aligned}
$$

[Step 2] 周波数 $f_{1}$ の独立成分の順序を基準とする。 $k=2$ とおく。

$$
\mathbf{U}\left(f_{1}, t_{s} ; i\right)=\mathbf{z}\left(f_{1}, t_{s} ; i\right), \quad(i=1, \ldots, m)
$$

[Step 3] 周波数 $f_{k}$ のエンベロープと周波数 $f_{1}$ から $f_{k-1}$ までを統合した $\left(k=2\right.$ のとき, 周波数 $f_{1}$ の) エンベロープの 相関を最大化する順列 $\sigma(i)$ を決定する。これは, $i=1, \ldots, m$ において可能な順列の中で,

$$
\sum_{i=1}^{m} \varepsilon \mathbf{z}\left(f_{k} ; \sigma(i)\right) \cdot\left(\sum_{j=1}^{k-1} \varepsilon \mathbf{U}\left(f_{j} ; i\right)\right) .
$$

を最大化することで求めることができる。

[Step 4] Step 3 で求めた順列 $\sigma(i)$ に基づいて,

$$
\mathbf{U}\left(f_{k}, t_{s} ; i\right)=\mathbf{z}\left(f_{k}, t_{s} ; \sigma(i)\right), \quad(i=1, \ldots, m) \cdots \cdots
$$

とおく。

[Step 5] $k<m$ ならば $k=k+1$ とし, Step 3 に戻る。 以上により，順序の任意性を取り除いたスペクトログラ ム $\mathbf{U}\left(f, t_{s} ; i\right)$ を得ることができる。

〈2.5〉信号の復元 ICAにより得られたスペクトロ グラム $\mathbf{U}\left(f, t_{s} ; i\right)$ に逆フーリエ変換を適用して信号を復元す る。これにより, 複数 PD 源からの放射電磁波を PD ごと に分離することができる。

\section{3. ベイジアンネットによる到来角推定法}

各独立成分の到来角推定には，ベイジアンネットを用い

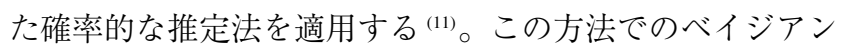
ネットの構成を図 1 に示す。 $\mathrm{T} 1_{\mathrm{n}}, \mathrm{T} 2_{\mathrm{n}}$ は, 各時刻におけ る両アンテナの受信信号の状態を表すノードであり,ノー 


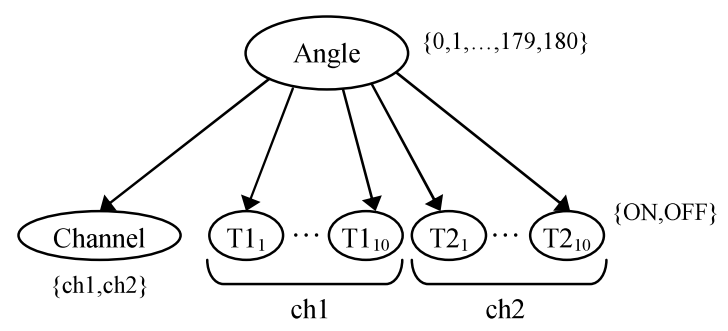

図 1 ベイジアンネットの構成

Fig. 1. Configuration of Bayesian network.

ドへの受信信号の入力は両アンテナで受信した信号のどち らか一方でも閾值を超えた時刻から開始する。ノードの状 態は $\{\mathrm{ON}, \mathrm{OFF}\}$ の 2 值であり，入力開始から最初に受信 信号が間值を超えた時刻に“ON”，それ以外は“OFF”とす る。Channel は最初に閾值を超えたチャンネルを表すノー ドであり，\{ch1，ch2\}の 2 状態を持つ。Angle は到来角を 表すノードで, $0 \sim 180^{\circ}$ の整数として $\{0,1, \ldots, 179,180\}$ の 181 状態を持ち，1ํ単位で到来角を推定する。

ここでは，複数設定した閾值に対してそれぞれ信号の到 達時間差を利用して到来角を求める。さらに，各閾值にお いてベイジアンネットから得た確率で重み付けした平均を 計算することで信号の到来角を推定する。

\section{4. 位置標定アルゴリズム}

本論文で提案する位置標定法の手順を図 2 に示し，以下 にその概要を述べる。アンテナで受信した信号をSTFTに より時間周波数領域に変換する。次に, 周波数成分ごとに 白色化，ICA を行い，信号を分離する。分離後の独立成分 は，逆行列を用いて振幅值，符号の任意性を解消した後，工 ンベロープを利用して順序の入れ替えを行い，周波数成分を 統合する。統合した信号に逆フーリエ変換（IDFT：Inverse Discrete Fourier Transform）を適用して観測信号を復元し, 独立成分ごとに到来角の推定を行う。到来角の推定には, 信号の振幅を利用したベイジアンネットによる確率的推定 法を利用する。このような STFT から到来角推定までの過 程を各所のアンテナで受信した信号について行う。最後に, 各所の観測信号から得た独立成分間の相関を求めることで, 同一PD からの信号を識別し，その信号を用いて到来角の 交点計算，PD の位置標定を行う。

\section{5. 位置標定シミュレーション}

提案手法に基づき，2䇢所から同時に放射した模擬信号 の位置標定シミュレーションを行った。シミュレーション では, 観測領域内に 4 つの信号源を置き，そのうち任意の 2 箇所から同時に発生した信号を 2 箇所に設置した 2 チャン ネルのアンテナ（間隔 $1 \mathrm{~m}$ ) (1)(11) で観測し，位置標定を行っ たと仮定した。図 3 に信号源とアンテナの配置図を示す。

観測領域のサイズは 6 通りであり，各サイズにおいて全 ての信号源の組合せで推定を行った。観測領域のサイズと アンテナ，信号源の座標を表 1 に示す。同表において，例

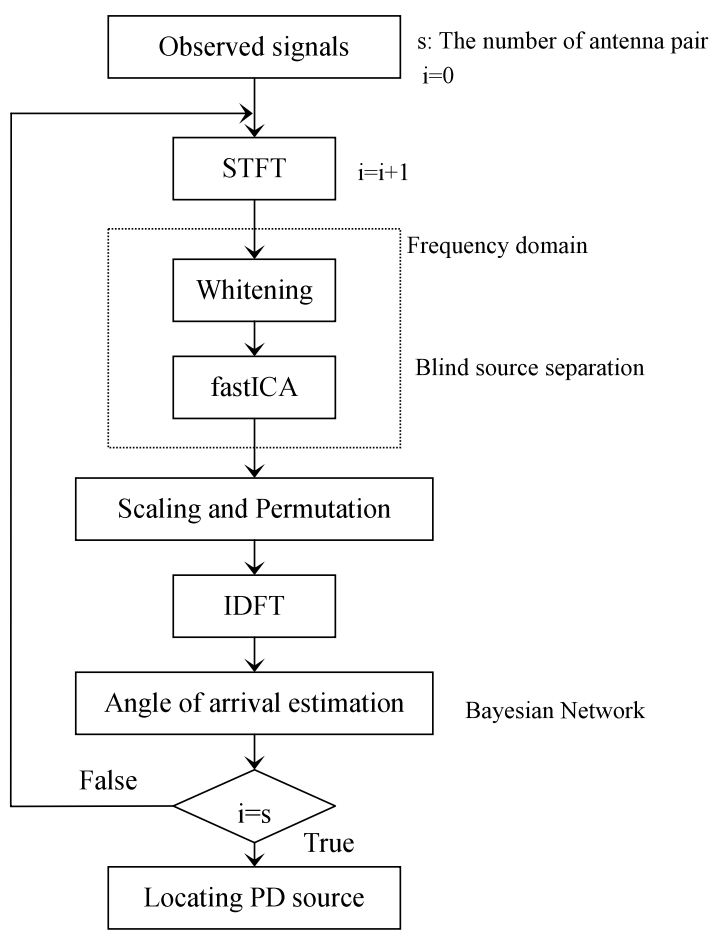

図 2 位置標定の手順

Fig. 2. Procedure of locating signal sources.

えば， $10 \mathrm{~m} \times 10 \mathrm{~m}$ のサイズ（図 3）では X座標 $-5 \mathrm{~m}$ から $5 \mathrm{~m}$, かつ Y 座標 $0 \mathrm{~m}$ から $10 \mathrm{~m}$ の領域が観測領域を示して いる。2 組のアンテナは観測領域の境界となる 2 辺の各中 点に配置し，信号源は $10 \mathrm{~m} \times 10 \mathrm{~m}$ の座標を基準に領域の 一辺の距離に比例した位置べクトルの座標に配置した。

図 4 に信号源から放射する模擬信号を示す。同図は (25) 式，(26) 式に示す $50 \mathrm{MHz}$ から $550 \mathrm{MHz}$ まで $50 \mathrm{MHz}$ 刻 みで加算した正弦波の合成波であり，これらの信号は周波 数成分の振幅值, 空関数が異なる。なお，本論文のシミュ レーションでは, 放射, 受信電磁波の電界強度を電圧值に 変換して表示している。

$$
\begin{aligned}
& s 1(n)=W 1(n) \sum_{m=1}^{11}\left\{\sqrt{m} \cdot \sin \left(2 \pi \cdot 50 \cdot 10^{6} \cdot m \cdot n \cdot \Delta t\right)\right\} \\
& W 1(n)=0.4-0.4 \cos \left(2 \cdot 2 \pi \cdot \frac{n}{N}\right) \ldots \ldots \ldots \ldots \\
& s 2(n)=W 2(n) \sum_{m=1}^{11}\left\{\sqrt{12-m} \cdot \sin \left(2 \pi \cdot 50 \cdot 10^{6} \cdot m \cdot n \cdot \Delta t\right)\right\} \\
& W 2(n)= \begin{cases}0.8 & \text { if }(N / 4 \leq n \leq N / 2) \\
0 & \text { otherwise }\end{cases}
\end{aligned}
$$

但し，N は解析空幅（ポイント数）である。 2 つのアンテナで受信する観測信号は

$$
\begin{aligned}
& x 1(t)=a_{11} \cdot s 1\left(t-\tau_{11}\right)+a_{12} \cdot s 2\left(t-\tau_{12}\right) \cdots \\
& x 2(t)=a_{21} \cdot s 1\left(t-\tau_{21}\right)+a_{22} \cdot s 2\left(t-\tau_{22}\right) \cdots
\end{aligned}
$$


表 1 アンテナと信号源の座標

Table 1. The antenna and signal source position.

\begin{tabular}{|c|c|c|c|c|c|c|}
\hline Observable area $[\mathrm{m}]$ & Antenna pair 1 & Antenna pair 2 & Source1 & Source2 & Source3 & Source4 \\
\hline $10 \mathrm{~m} * 10 \mathrm{~m}: \mathrm{X}[-5,5], \mathrm{Y}[0,10]$ & $\operatorname{ch} 1(0,0), \operatorname{ch} 2(1,0)$ & $\operatorname{ch} 1(5,4), \operatorname{ch} 2(5,5)$ & $(-2.5,7.5)$ & $(-2,3)$ & $(2,4)$ & $(2,7)$ \\
\hline $20 \mathrm{~m} * 20 \mathrm{~m}: \mathrm{X}[-10,10], \mathrm{Y}[0,20]$ & $\operatorname{ch} 1(0,0), \operatorname{ch} 2(1,0)$ & $\operatorname{ch} 1(10,9), \operatorname{ch} 2(10,10)$ & $(-5,15)$ & $(-4,6)$ & $(4,8)$ & $(4,14)$ \\
\hline $40 \mathrm{~m} * 40 \mathrm{~m}: \mathrm{X}[-20,20], \mathrm{Y}[0,40]$ & $\operatorname{ch} 1(0,0), \operatorname{ch} 2(1,0)$ & $\operatorname{ch} 1(20,19), \operatorname{ch} 2(20,20)$ & $(-10,30)$ & $(-8,12)$ & $(8,16)$ & $(8,28)$ \\
\hline $60 \mathrm{~m} * 60 \mathrm{~m}: \mathrm{X}[-30,30], \mathrm{Y}[0,60]$ & $\operatorname{ch} 1(0,0), \operatorname{ch} 2(1,0)$ & $\operatorname{ch} 1(30,29), \operatorname{ch} 2(30,30)$ & $(-15,45)$ & $(-12,18)$ & $(12,24)$ & $(12,42)$ \\
\hline $80 \mathrm{~m} * 80 \mathrm{~m}: \mathrm{X}[-40,40], \mathrm{Y}[0,80]$ & $\operatorname{ch} 1(0,0), \operatorname{ch} 2(1,0)$ & $\operatorname{ch} 1(40,39), \operatorname{ch} 2(40,40)$ & $(-20,60)$ & $(-16,24)$ & $(16,32)$ & $(16,56)$ \\
\hline $100 \mathrm{~m} * 100 \mathrm{~m}: \mathrm{X}-50,50], \mathrm{Y}[0,100]$ & $\operatorname{ch} 1(0,0), \operatorname{ch} 2(1,0)$ & $\operatorname{ch} 1(50,49), \operatorname{ch} 2(50,50)$ & $(-25,75)$ & $(-20,30)$ & $(20,40)$ & $(20,70)$ \\
\hline
\end{tabular}

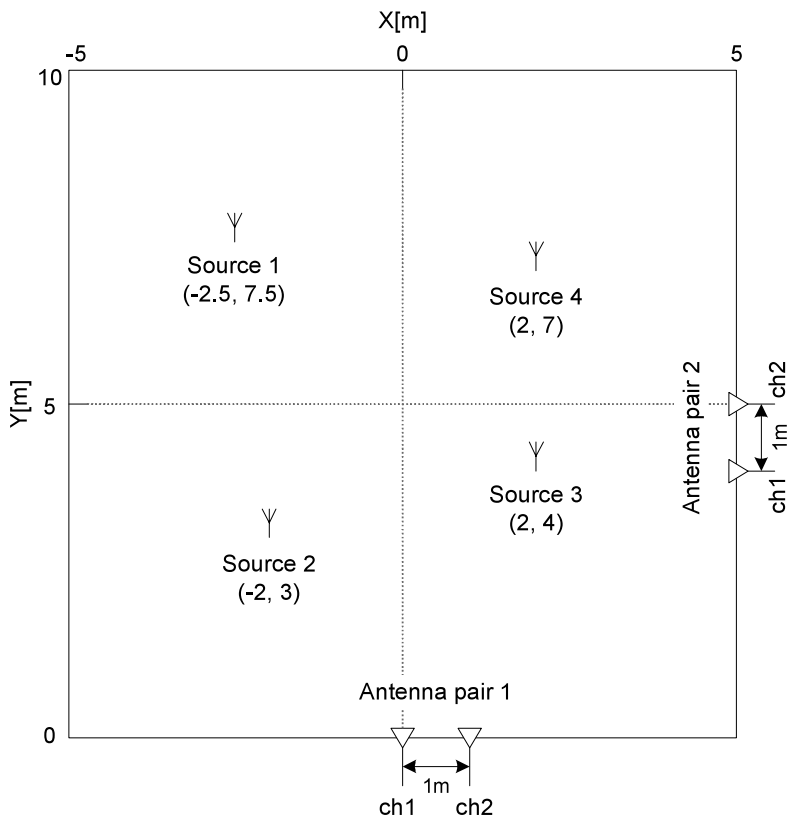

図 3 信号源とアンテナの配置図

Fig. 3. Configuration of source signals and antennas.

$\tau_{n m}$ : 信号源 $m$ からアンテナのチャンネル $n$ まで の原信号の到達時間。

となり，時間の遅れを含む時空間的混合となる。なお，両 PD 源から放射される電磁波は同一空間を伝搬，同一の受信 アンテナの利用，ベイジアンネットによる到来角推定法に おいて，相互結合の影響をベースライン付近の到来角 (ベー スラインから $16^{\circ}$ の範囲) のみに抑えていることから, 本シ ミュレーションでは, 各信号源とアンテナまでの距離 $\mathrm{R}$ の みを混合行列 $\mathbf{A}$ の要素とした。係数 $a_{11}, a_{12}, a_{21}, a_{22}$ は 各信号源からアンテナまでの距離 $\mathrm{R}$ を用いて $1 / \mathrm{R}$ とし, 有 効桁数は距離による減衰を考慮して小数点以下 5 桁とした。

上記のシミュレーション環境において, 提案法による信 号源の位置標定を行った。観測領域のサイズ $60 \mathrm{~m} \times 60 \mathrm{~m}$, source1 と source4 から放射された信号 $s 1$, s2（図 4) を Antenna pair1 (ch1, ch2) で受信した信号 $x 1, x 2$ を図 5 に示 す。同図の ch1, ch2 での観測信号 $x 1, x 2$ は (27) 式を用い

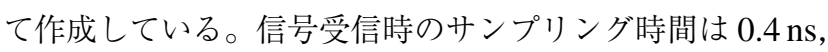
解析空幅は 2048point (819.2 ns), STFT の空関数はハニン

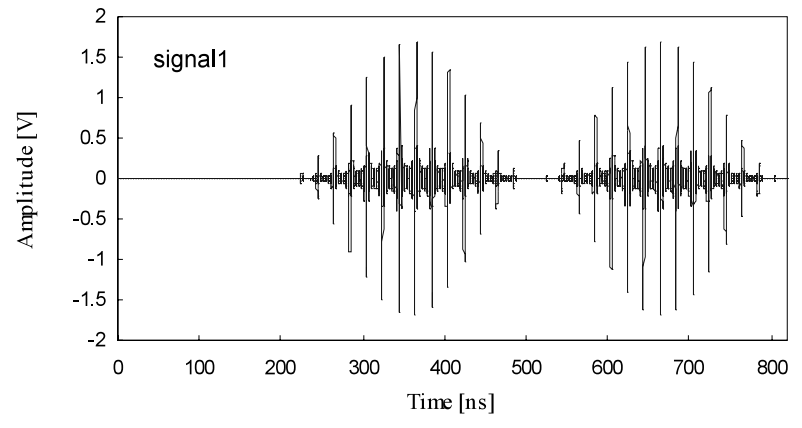

(a) Signal1

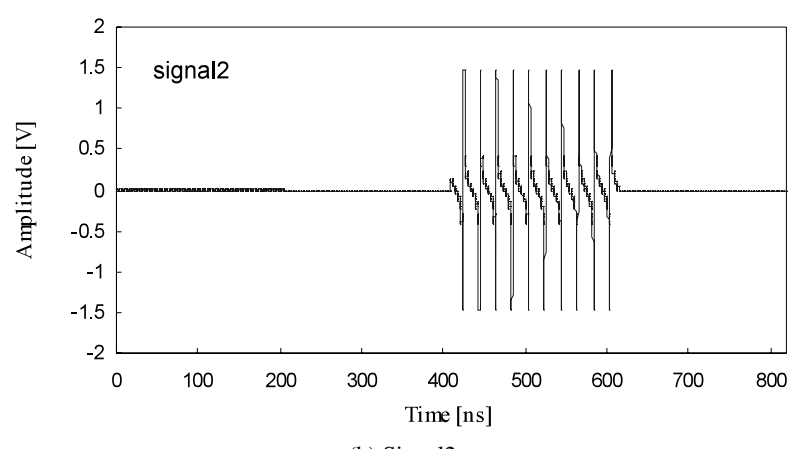

(b) Signal2

図 4 原信号

Fig. 4. Source signals.

グ空 (Hanning window), 幅は 512point (204.8ns), 空関 数の単位移動時間幅は 16point $(6.4 \mathrm{~ns})$ とした。

観測信号 $x 1 ， x 2$ から，ICA により推定した信号を図 6 に示す。同図の振幅は (17) 式により, アンテナの ch1 での 受信時を推定したものである。同図と図 4 の原信号を比較 すると，概ね良好に分離できていることが分かる。

提案法により求めた信号源位置と設定位置との距離の平 均誤差を図 7 に示す。また, 位置標定の過程で求めた信号 の到来角の平均誤差を図 8 に示す。図 7, 図 8 より, 観測 領域 $10 \mathrm{~m} \times 10 \mathrm{~m}$ では距離の誤差が $0.59 \mathrm{~m}$, 到来角の誤差

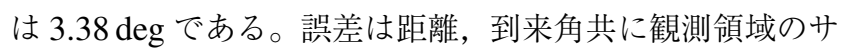
イズにほほ比例して大きくなり，100 m×100 m では距離 $8.86 \mathrm{~m}$, 到来角 $4.68 \mathrm{deg}$ となっている。到来角に比べ, 距 離の誤差が大きくなっているが, これは同じ到来角の誤差 であっても信号源がアンテナから遠くなるに従い，交点を 求める際の誤差が大きくなるためである。また, 交点を求 


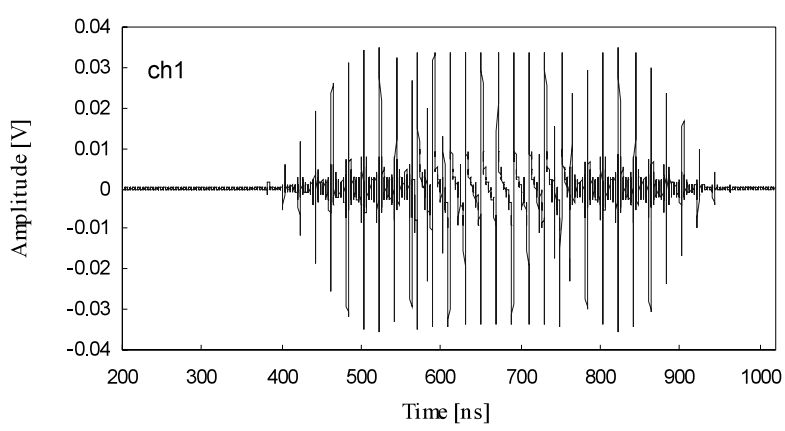

(a) Ch1

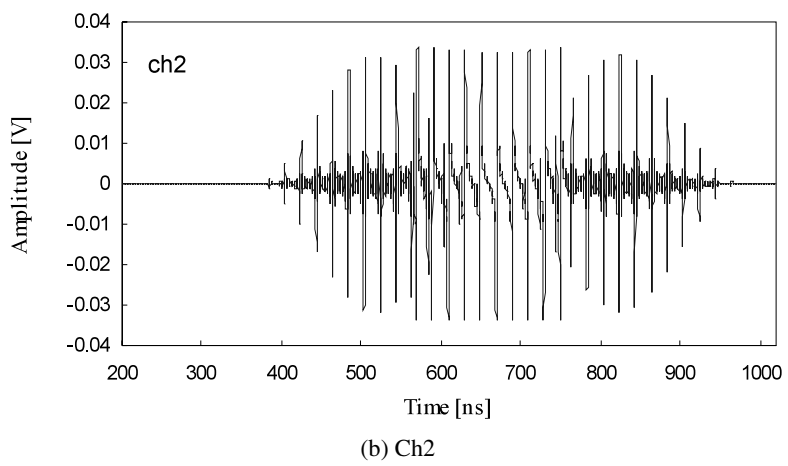

図 5 観測信号

Fig. 5. Observed signals.

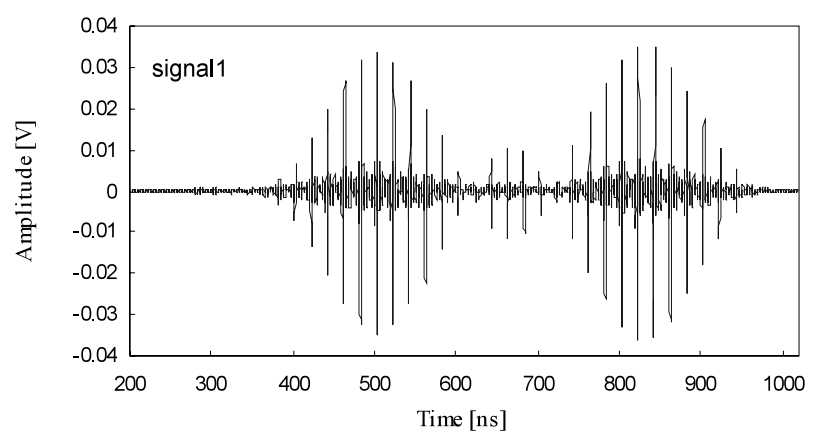

(a) Signal1

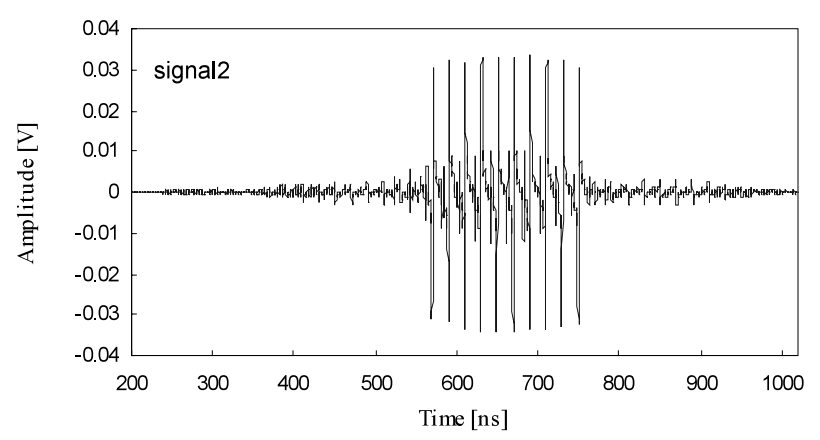

(b) Signal2

四 6 分離信号

Fig. 6. Separated signals.

める際の到来角の誤差がプラス方向であるか, マイナス方 向であるかの組合せも距離の誤差に影響している。このよ うな誤差はアンテナの設置数を増やし, 複数の交点から重 心を求めることで減じることができる ${ }^{(5)}$ 。なお, 観測領域

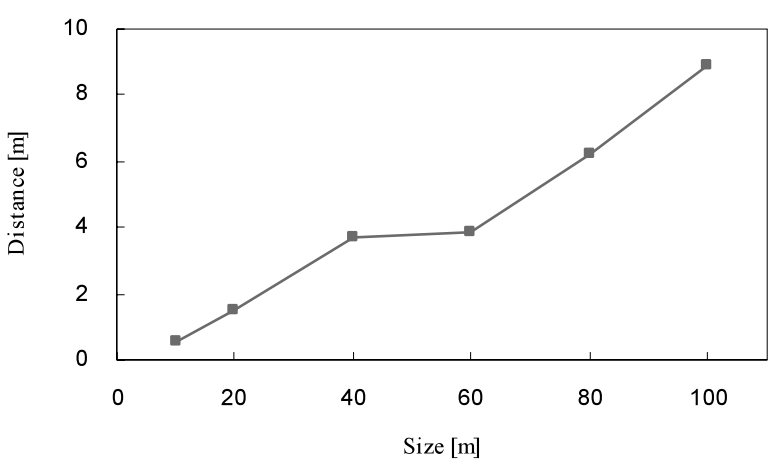

図 7 距離の平均推定誤差

Fig. 7. Averaged estimation error (distance).

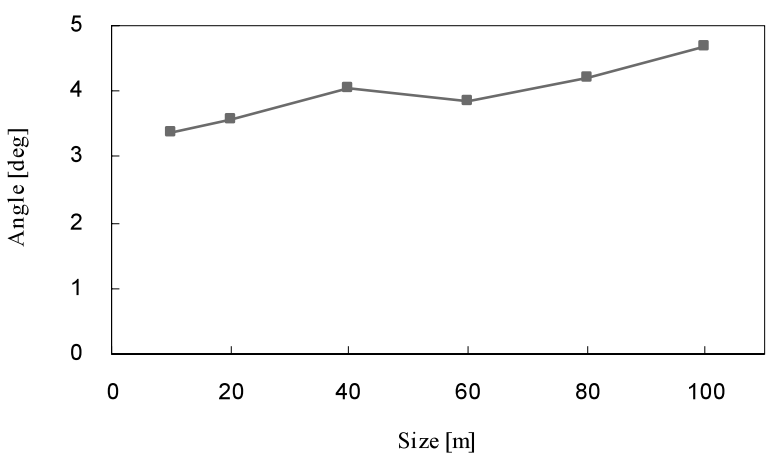

図 8 到来角の平均推定誤差

Fig. 8. Averaged estimation error (angle of arrival).

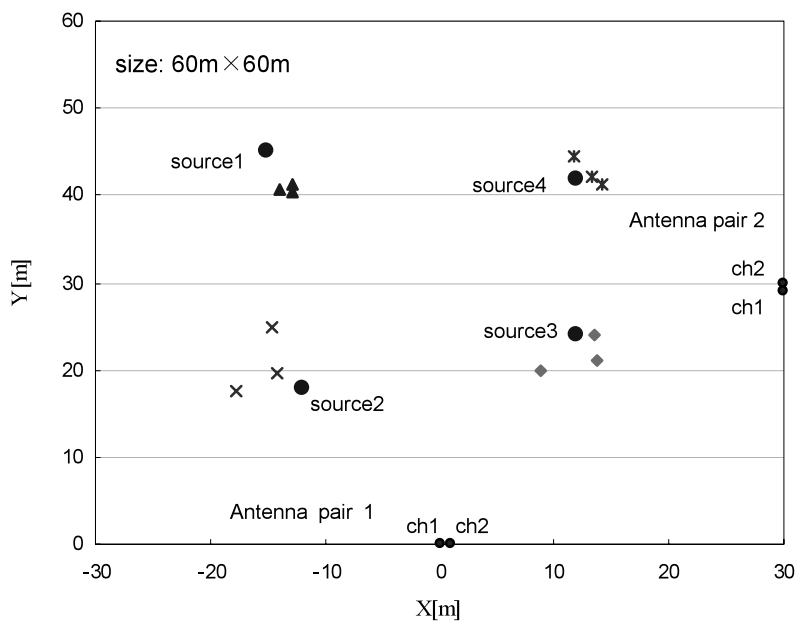

図 9 推定結果

Fig. 9. Estimation result.

$40 \mathrm{~m} \times 40 \mathrm{~m}$ では, ICA による分離が不完全な推定結果が 含まれていたため，誤差が大きくなっている。

一例として, 図 9 に観測領域 $60 \mathrm{~m} \times 60 \mathrm{~m}$ の位置標定結 果を示す。なお, 同図中の source1〜4 周辺の*印等は本手 法による推定位置である。推定は各信号源について, 残り の 3 つの信号源とそれぞれ同時に信号が発生した場合を仮 定して行ったため，推定結果は各信号源に対して 3 つずつ 示している。同図より, 本手法が複数信号源の位置標定に 対して有効であることが分かる。 


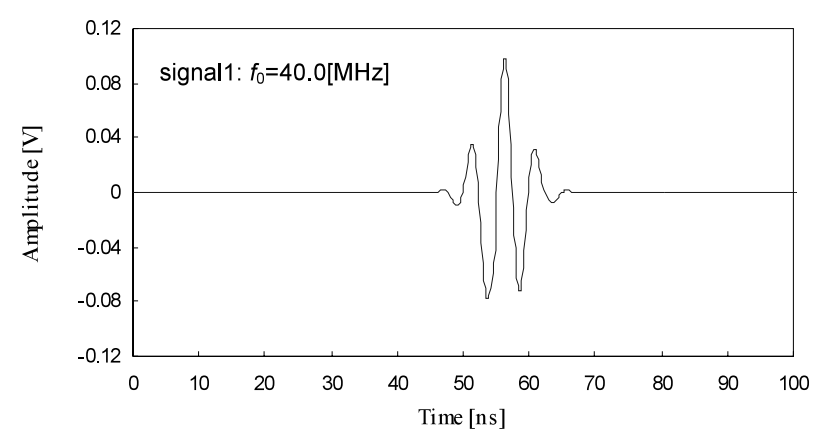

(a) Signal1

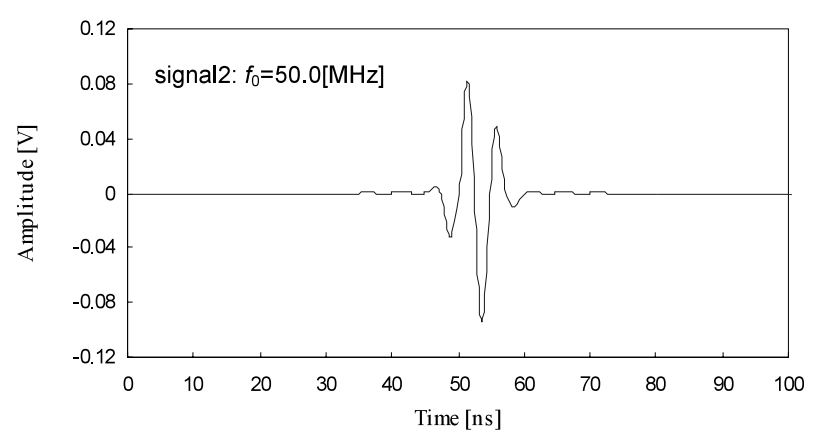

(b) Signal2

図 10 原信号

Fig. 10. Source signals.

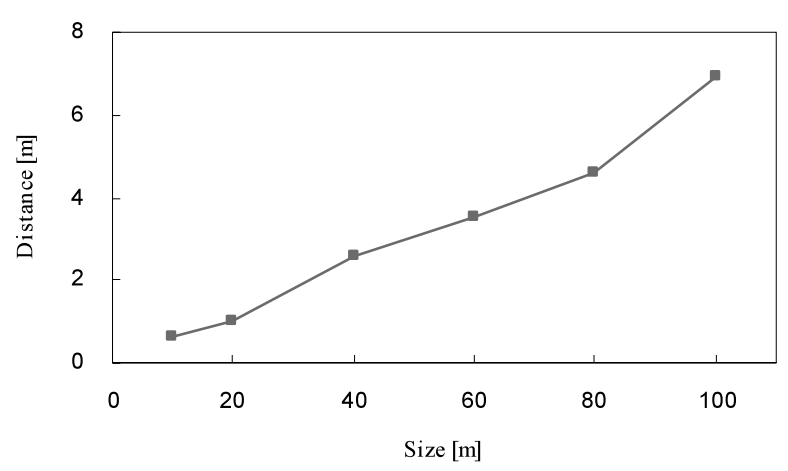

図 11 距離の平均推定誤差

Fig. 11. Averaged estimation error (distance).

次に, 実際の PD 放射電磁波を考慮し, (28) 式に示すガ ウシアンパルスと CW (Continuous Wave) による波形を 模擬信号源として同様のシミュレーションを行った。困 10 に信号源から放射される信号波形を示す。同図の信号はス ペクトルが $3 \mathrm{~dB}$ 低下する周波数 $f_{0}$ が異なる。

$$
s(n)=0.1 \exp \left[-\{(n \cdot \Delta t-T) / 0.29 T\}^{2}\right] \cdot \sin \left(2 \pi \cdot 0.2 \cdot 10^{9} \cdot n \cdot \Delta t\right)
$$

$$
T=0.646 / f_{0}
$$

提案法により求めた信号源位置と設定位置との距離の平 均誤差を図 11 に示す。同図より, 観測領域 $10 \mathrm{~m} \times 10 \mathrm{~m}$ で は誤差 $0.60 \mathrm{~m}$ であり, 上記のシミュレーションとほぼ同じ 結果となった。誤差は観測領域のサイズに比例して大きく なっているが, 図 7 と比較すると全体的に誤差は小さい。
これは, 受信信号の立ち上がりから最大值までの時間が短 くなったため, 振幅の閾值を利用した到来角推定の誤差が 減少し, その結果として, 距離の誤差も減少したと考えら れる。以上より, 提案法が複数 PD 源の位置標定に対して 有効であることが分かる。

\section{6. まとめ}

本論文では, 複数箇所で発生したPD 源の位置標定法と して, ICA とベイジアンネットによる電磁波到来角推定法 を適用した手法を提案した。

模擬信号によるシミュレーションの結果, 観測領域 $10 \mathrm{~m} \times 10 \mathrm{~m}$ であれば誤差 $0.60 \mathrm{~m}$ 程度で受信信号の個々の 信号源を推定できることを確認した。なお，観測領域が小 さくなるに伴い, 推定誤差が減少することから, 観測領域 が広域であっても, 観測領域を狭めるように, 本手法を段 階的に複数回適用することで誤差 $0.6 \mathrm{~m}$ 以下での推定が可 能である。

本手法は, 変電所構内の変圧器ブッシング, ガス遮断器 ブッシングやケーブル端末等, 及び送電・配電系統の各種 機器等での PD 発生有無や位置標定に有効であると考えら れる。また，ガス絶縁開閉装置（GIS）等内にアンテナを 挿入した場合についても検討が必要であるが, 各種劣化原 因による放射電磁波や, 異なった位置から放射される電磁 波の分離にも利用できる可能性がある。また, 実際の環境 においては，ブッシングからの引き出し線やがいしなどか らのコロナ放電と機器内の PD との識別が必要となること がある。これには, 周波数分布によるパターン認識手法の 適用が考えられる。

本論文では, 発生したPD 源の数が予め分かっているこ とを前提に位置標定を行ったが，これは観測信号の空間相 関行列の固有值を分析することで推定が可能である。

今後は, 各種電力機器・設備における電磁波反射に伴う マルチパスの影響も考慮に入れた検討を行う予定である。

\section{謝 辞}

本研究は, 科学技術振興機構, 文部科学省 (科学研究補助 金若手研究 (B)16760230), 徳島大学 (工学部研究プロジェ クト), 財団法人池谷科学技術振興財団 (研究助成), 財団 法人中部電力基礎技術研究所 (出版助成) 等により助成頂 きましたことを付記し，ここに謝意を表します。

日頃より，貴重なご意見を賜ります徳島大学・伊坂勝生 教授に謝意を表します。

(平成 17 年 11 月 16 日受付, 平成 18 年 7 月 6 日再受付)

\section{文献}

(1) M. Kawada: "Fundamental Study on Locating Partial Discharge Source using VHF-UHF Radio Interferometer System", T. IEE Japan, Vol.122-B, No.5, pp.629-636 (2002-5) (in Japanese)

川田昌武：「VHF-UHF 带電波干渉計システムによる部分放電源特定 のための基礎研究」,電学論 B, 122, 5, pp.629-636 (2002-5) 
(2) M. Hikita: "Future Trend of Discharge Measurement Technique for Diagnosis of Insulation Performance of Electric Power Apparatus", T. IEE Japan, Vol.121-B, No.6, pp.695-698 (2001-6) (in Japanese)

匹田政幸:「電力機器の絶縁診断における部分放電測定技術の動向」, 電学論 B, 121, 6, pp.695-698 (2001-6)

(3) H. Maekawa, M. Doi, and S. Kawamoto: "Identification for Sources of Partial Discharge in Gas Insulated Switchgears", T. IEE Japan, Vol.120-B, No.8/9, pp.1106-1111 (2000-8/9) (in Japanese)

前川 洋・土井雅史・川本俊治：「ガス絶縁開閉装置における部分放 電源の同定」, 電学論 B, 120,8/9, pp.1106-111 (2000-8/9)

(4) H. Tsutada, N. Nagata, M. Miyashita, M. Kamei, S. Inoue, K. Takashima, and T. Usami: "Detection of Partial Discharge Using First Peak Height and Cumulative Wave Parameter of Internal Electromagnetic Wave in GIS", T. IEE Japan, Vol.120-B, No.3, pp.333-339 (2000-3) (in Japanese)

蔦田広幸·長田典子·宮下 信 ·龟井光仁 ·井上 悟 · 高嶋和夫 · 宇佐美照夫：「GIS 内部電磁波の第一波波高值と累積波形指標を用 いた部分放電識別」, 電学論 B, 120, 3, pp.333-339 (2000-3)

(5) Y. Suzuki, M. Kawada, Z. Kawasaki, K. Matsuura, and M. Kawasaki: "Location of Partial Discharge by Superimposed Positioning Optimization on the Time Delay of Arrival", T. IEE Japan, Vol.118-B, No.2, pp.157-163 (1998-2) (in Japanese)

鈴木雄一・川田昌武·河崎善一郎 · 松浦虔士 · 川崎 誠 :「位置標定 における重畳最適化法を用いた部分放電源空間標定」, 電学論 B, 118, 2, pp.157-163 (1998-2)

(6) M. Kawada, Z. Kawasaki, K. Matsuura, and M. Kawasaki: "Non-Contact Detection of Electromagnetic Noise Occurrence due to Partial Discharges by Spatial Phase Difference Method", T. IEE Japan, Vol.115-B, No.10, pp.1168-1173 (1995-10) (in Japanese)

川田昌武・河崎善一郎・松浦虔士 ·川崎 誠：「電磁波空間位相差 法を用いた非接触部分放電検出法」, 電学論 B, 115, 10, pp.1168-1173 (1995-10)

(7) M. Kawada, J. Abe, and Z. Kawasaki: "Location of Partial Discharge by Superimposed Positioning Optimization on the Time Delay of Arrival", $T$. IEE Japan, Vol.118-B, No.7/8, pp.908-909 (1998-7/8) (in Japanese) 川田昌武·安部淳一・河崎善一郎：「ウェーブレット変換を用いた電磁 波時空間位相差法による部分放電検出」, 電学論 B, 118, 7/8, pp.908-909 (1998-7/8)

(8) A. Tungkanawanich, Z. Kawasaki, and K. Matsuura: "Location of Multiple PD Sources on Distribution Lines by Measuring Emitted Pulse-Train Electromagnetic Waves", T. IEE Japan, Vol.120-B, No.11, pp.1431-1436 (2000-11)

(9) C.H. Peck and P.J. Moore: "A Direction-Finding Technique for WideBand Impulsive Noise Source", IEEE Trans. Electromagnetic Compatibility, Vol.43, No.2, pp.149-154 (2001-5)

(10) H. Okubo: "Recent Research Activity and Future Trend of Electrical Insulation Diagnostic Technique for Electric Power Apparatus", T. IEE Japan, Vol.119-B, No.4, pp.434-437 (1999-4) (in Japanese)

大久保仁:「電力機器の診断技術の現状と今後の課題」, 電学論 $\mathrm{B}, \mathbf{1 1 9}$ 4, pp.434-437 (1999-4)
(11) H. Ishimaru and M. Kawada: "Fundamental Study on Direction Finding Technique for Electromagnetic Waves Emitted from a Partial Discharge using Bayesian Network", IEEJ Trans. PE, Vol.125, No.2, pp.177-183 (20052) (in Japanese)

石丸宏一・川田昌武：「ベイジアンネットによる部分放電放射電磁 波の方位角推定法に関する基礎研究」, 電学論 B, 125, 2, pp.177-183 (2005-2)

12） A. Hyvärinen, J. Karhunen, and E. Oja （根本 幾 · 川勝真喜訳）：詳解 独立成分分析一信号解析の新しい世界, 東京電機大学出版局 (2005-2)

（13）村田 昇：入門独立成分分析, 東京電機大学出版局 (2004-7)

(14) T.-W. Lee, M.S. Lewicki, M. Girolami, and T.J. Sejnowski: "Blind Source Separation of More Sources Than Mixtures Using Overcomplete Representations", IEEE Signal Processing Lett., Vol.6, No.4, pp.87-90 (1999-4)

(15) K.H. Knuth: "A Bayesian Approach to Source Separation", Proceedings of the First International Workshop on Independent Component Analysis and Signal Separation: ICA'99, pp.283-288, Aussois, France (1999-1)

(16) E. Bingham and A. Hyvärinen: "A Fast Fixed-Point Algorithm for Independent Component Analysis of Complex Valued Signals", Int. J. Neural Systems, Vol.10, No.1, pp.1-8 (2000-2)

(17) N. Murata, S. Ikeda, and A. Ziehe: "An Approach to Blind Source Separation Based on Temporal Structure of Speech Signals", Neurocomputing, Vol.41, Issue 1-4, pp.1-24 (2001-10)

石丸宏 一 (正員) 1977 年 2 月 14 日生。1999 年 3 月同志

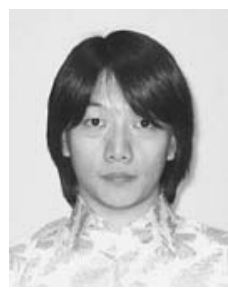
社大学工学部知識工学科卒業。同年 4 月同大学大 学院工学研究科知識工学専攻修士課程進学。2000 年 3 月退学。同年 4 月名古屋工業大学工学部シス テムマネジメント工学科勤務。2006 年 10 月徳島 大学大学院博士後期課程入学。統計的信号処理の 研究に従事。

川田昌 武 (正員) 1971 年 1 月 25 日生。1998 年大阪大学

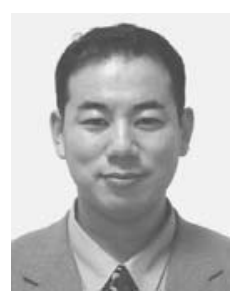
大学院電気工学博士後期修了。同年名古屋工業大 学工学部助手, 2002 年徳島大学工学部講師, 2003 年助教授。2005 年米国 USC 客員 (文科省)。博 士 (工学)。電力機器診断, 信号処理, 環境生体 電磁, 脳電磁情報研究に従事。IEEE 会員。 